\title{
Status of zinc nutrition in Bangladesh: the underlying associations
}

\author{
Sabuktagin Rahman ${ }^{1}$, Tahmeed Ahmed ${ }^{1}$, Ahmed Shafiqur Rahman ${ }^{1}$, Nurul Alam ${ }^{2}$, \\ A. M. Shamsir Ahmed ${ }^{1,3}$, Santhia Ireen ${ }^{1}$, Ireen Akhter Chowdhury ${ }^{4}$, Fatima Parveen Chowdhury ${ }^{5,6}$ \\ and S. M. Mustafizur Rahman ${ }^{6,7}$ \\ ${ }^{1}$ Nutrition and Clinical Services Division, International Centre for Diarrboeal Disease Research (ICDDR,B), 68 Shaheed Tajuddin Ahmed Sharani, \\ Mohakhali Dhaka 1212, Bangladesh \\ ${ }^{2}$ Health Systems and Population Studies Division, ICDDR,B, 68 Shaheed Tajuddin Ahmed Sharani, Mohakhali Dhaka 1212, Bangladesh \\ ${ }^{3}$ School of Public Health, Faculty of Medicine and Biomedical Sciences, The University of Queensland, Herston, QLD, Australia \\ ${ }^{4}$ UNICEF, Bangladesh \\ ${ }^{5}$ Ayesha Memorial Medical College, Dhaka, Bangladesh \\ ${ }^{6}$ Institute of Public Health Nutrition, Dhaka, Bangladesh \\ ${ }^{7}$ Micronutrient Initiative, Dhaka, Bangladesh
}

(Received 22 December 2015 - Final revision received 17 March 2016 - Accepted 21 March 2016)

Journal of Nutritional Science (2016), vol. 5, e25, page 1 of 9

doi:10.1017/jns.2016.17

\section{Abstract}

Bangladesh is a country with a high burden of micronutrient malnutrition. Stunting affects $41 \%$ of children aged under 5 years. Zn is one of the key micronutrients that is associated with stunting. The present study, as part of the national micronutrient survey 2011-2012, revealed for the first time the nationally representative prevalence of Zn deficiency and determined the associations of the condition. A cross-sectional 'nationwide' survey was conducted in pre-school-age children (6-59 months; PSAC) and non-pregnant non-lactating women (15-49 years; NPNLW). Multistage random sampling was done in 150 clusters; fifty in each of the rural, urban and slum strata. Data were analysed on 662 PSAC and 1073 NPNLW. Serum Zn was assayed by atomic absorption spectrophotometry. Zn deficiency was defined as serum Zn of $<9.9$ and $<10.1 \mu \mathrm{mol} / 1$ in PSAC and NPNLW, respectively. The national prevalence of Zn deficiency was 44.6 and $57.3 \%$ in PSAC and NPNLW, respectively. In PSAC, it was 29.5, 48.6 and $51.7 \%$, respectively, in urban, rural and slum strata. Household expenses $(\beta=0.13 ; P=0.007), \mathrm{Hb}(\beta=0.10 ; P=0.005)$, intake of animal-source $\mathrm{Zn}(\beta=0.096 ; P=0.02)$ and asset score $(\beta=0.11 ; P=0.03)$ were positively associated with serum $Z n$ in NPNLW. Residence in an urban area $(\beta=0.33 ; P=0.03)$ and intake of plant-origin $\mathrm{Zn}(\beta=-0.13 ; P=0.038)$ determined higher and lower status of $\mathrm{Zn}$ in PSAC, respectively. Zn deficiency was highly prevalent in Bangladesh, and it was principally related to inadequate quality of diet. To improve $\mathrm{Zn}$ nutrition, Bangladesh needs to strengthen research and programmes related to Zn biofortification, fortification and phytate-reducing technologies in the food system in the short and medium term. In addition, promotion of animal-source $\mathrm{Zn}$ for all is important in the long run.

Key words: Zinc deficiency: Zinc intake: Children: Women in Bangladesh: Rural, urban and slum

$\mathrm{Zn}$ is one of the most important trace elements involved in human metabolism. It is implicated in all major biochemical metabolism and plays multiple roles in the maintenance of genetic material, including transcription of DNA, translation of RNA and cellular division ${ }^{(1)}$. Zn supplementation produces highly significant positive responses in linear growth and weight gain ${ }^{(2)}$. On the other hand, $\mathrm{Zn}$ deficiency is associated with stunted linear growth and diminished immune function.

Abbreviations: AGP, $\alpha$-1-acid glycoprotein; CRP, C-reactive protein; NPNLW, non-pregnant non-lactating women; PSAC, pre-school-age children; QC, quality control; SES, socio-economic status.

* Corresponding author: Dr S. Rahman, fax +8802 9827101, email rahman.sabuktagin@gmail.com 
Supplementation of the mineral is also associated with lessening of diarrheal duration and respiratory tract infection in children $^{(2)}$. Childhood stunting in children aged under 5 years is widely recognised as a proxy indicator of $\mathrm{Zn}$ deficiency. However, not until the present study was conducted in 2011-2012 were nationwide data of $\mathrm{Zn}$ deficiency available in Bangladesh, a country with a high prevalence of stunting in children aged under 5 years $(41 \%)^{(3)}$. The present study has revealed for the first time in Bangladesh the national estimates of subclinical $\mathrm{Zn}$ deficiency and the underlying associations of the condition.

\section{Methods}

\section{Sampling and study population}

The present study is a part of the national micronutrient survey 2011-2012 of Bangladesh. A multi-stage random sampling procedure was applied to select the study participants from the rural, urban and the slum domains distributed all over the country. In the first stage, 150 clusters (fifty clusters in each domain) from the 15000 clusters of the Bangladesh Multiple Indicator Cluster Sampling (MICS) ${ }^{(4)}$ frame were randomly selected. In the second stage a segment of fifty households was randomly chosen from each of the selected clusters and in the final stage, twenty households were selected randomly from the fifty-household segment; these twenty households formed the definitive sampling frame from which the required number of study participants was selected.

The sample size (Supplementary Table S3) for assessing Zn deficiency was representative of the stratum; however, combining all the three strata together and with application of population weight, nationally representative estimates were obtained. Data were collected in two population groups pre-school-age children (PSAC; 6-59 months) and nonpregnant non-lactating women (NPNLW; 15-49 years).

\section{Data and blood sample collection}

Data on socio-economic status (SES), household possession of assets, household construction material, household food insecurity, morbidity of children and food intake of the study participants were analysed. SES was assessed by constructing the wealth index ${ }^{(5)}$. Household food insecurity was assessed by the Household Food Insecurity Access Scale (HFIAS) for measurement of food access ${ }^{(6)}$. In order to assess food consumption, a semi-quantitative FFQ was used taking into consideration commonly consumed Bangladeshi foods ${ }^{(7-10)}$. The semi-quantitative FFQ assessed consumption over the preceding $7 \mathrm{~d}$ of the survey. The tool was administered by the field data collectors. For NPNLW, the study respondent provided the response; however, for PSAC, the mother or primary caretaker responded. The tools did not require the respondents to have any reading or writing skills necessary. The respondent was asked to tell about the number of portions (servings) of particular foods that she and/or her child had consumed over the past $7 \mathrm{~d}$. She was required to indicate the portion size $(\mathrm{g}, \mathrm{ml})$ of the consumption from the standardised food photographs or commonly used household utensils, which were displayed and explained at the time of the interview. The number of portions consumed over the past $7 \mathrm{~d}$ multiplied by the average size of the portions yielded the total weekly consumption ( $\mathrm{g}, \mathrm{ml})$. Raw food weight was calculated by using appropriate conversion factors ${ }^{(11)}$. The nutrient value for $\mathrm{Zn}$ was calculated per $100 \mathrm{~g}$ of raw food consumed using an updated Food Composition Table on Bangladeshi food $^{(12)}$. The prevalence of $\mathrm{Zn}$ intake inadequacy was measured by the estimated average requirement (EAR) cut-point $\operatorname{method}^{(1)}$. For children, we defined dietary $\mathrm{Zn}$ inadequacy using the EAR for 2- to 3-year-old children $(<2 \mathrm{mg} / \mathrm{d})^{(1)}$. For women, dietary $\mathrm{Zn}$ inadequacy was calculated by using lower bioavailability with an unrefined, cereal-based diet $(<7$ $\mathrm{mg} / \mathrm{d})^{(1)}$. Phytate is a chemical substance present in plant foods which acts as a chelator of minerals, including $\mathrm{Zn}$. The inhibitory effect of phytate on $\mathrm{Zn}$ absorption appears to follow a dose-dependent response, and the phytate: $\mathrm{Zn}$ molar ratio of the diet has been used to estimate the proportion of absorbable $\mathrm{Zn}^{(1)}$. To classify populations according to mixed or cereal-based diet types, the phytate: $\mathrm{Zn}$ molar ratio of foods or diets was calculated according to the methods described in the technical document of the International Zinc Nutrition Consultative Group ${ }^{(1)}$. Blood samples were collected in a centralised location, such as school, health centre, non-governmental organisation (NGO) office, developed as temporary sample collection centres. The selected survey respondents were given a token number indicating their names and identification and guided to appear at the collection centres. Venous blood was collected in trace element-free venoject tubes. The blood tubes were placed in a cool box and allowed to clot. The whole blood was centrifuged (Portable Centrifuge, 3000-3500 rpm) at the field collection centre and the serum was aliquoted in cryovials (trace element free) using a disposable pipette. The cryovials were stored in a $-20^{\circ} \mathrm{C}$ freezer. Aliquoted serum samples were transferred in dry ice to the Nutritional Biochemistry Laboratory at the International Centre for Diarrhoeal Disease Research, Bangladesh (ICDDR,B), and stored in a $-70^{\circ} \mathrm{C}$ freezer. The study received ethical approval from the Institutional Review Board of ICDDR,B. Written informed consent was taken from all study participants.

\section{Biochemical analysis}

We assayed serum $\mathrm{Zn}$ by atomic absorption spectrophotometry (Shimadzu AA-7000). C-reactive protein (CRP) and $\alpha$-1-acid glycoprotein (AGP) were analysed by sandwich ELISA (Dynex Technologies Inc.). Hb was assessed using HemoCue Hb 301 (Hemocue AB) on venous blood.

\section{Adjusting for infection}

Serum $\mathrm{Zn}$ level was adjusted for infection by estimating biomarkers of infection - CRP and AGP. We performed the adjustment for elevated levels of CRP $(>10.0 \mathrm{mg} / \mathrm{l})$ and AGP $(>1.0 \mathrm{~g} / \mathrm{l})$ by deriving the correction factors following the methods described by Thurnham et al. ${ }^{(13)}$ and Engle-Stone et al. ${ }^{(14)}$. 


\section{Quality control}

All biochemical analyses were carried out in the nutritional biochemistry laboratory of ICDDR,B. To control the quality of the laboratory analyses pooled serum and commercial quality-control (QC) material (Bi-level serum toxicology control; UTAK Laboratories, Inc.) were used for $\mathrm{Zn}$. Pooled serum had the assigned value against the standard reference material. The pooled serum was stored in a freezer $\left(-20^{\circ} \mathrm{C}\right)$ and analysed with every batch of samples along with the commercial control material. If the values of these preliminary analyses had fallen within the assigned ranges for the QC, the regular QC assays (pool and commercial) for all samples were performed. The mean values for the pool and the commercial QC along with standard deviations and 95\% CI were calculated. For $\mathrm{Zn}$, the $\mathrm{CV}$ against the pooled serum, QC-normal and QC-high were 4.5, 4.1 and 4.0\%, respectively. Precinorm protein and Precipath protein (Roche Diagnostics $\mathrm{GmbH}$ ), as QC, were used to check the accuracy and precision of CRP and AGP. The CV for CRP and AGP measurement were 3.9 and $5.9 \%$, respectively. We participated in the VITAL-EQA (Centers for Diseases Control) for CRP.

\section{Sample size}

The sample size to estimate $\mathrm{Zn}$ undernutrition was calculated based on the prevalence of low serum $\mathrm{Zn}$ observed in a contemporary study in Bangladesh ${ }^{(15)}$. The required sample size for PSAC and NPNLW was 969 and 1500, respectively, taking into consideration an attrition factor of 1.2 and a design effect $2 \cdot 0$. However, the final analysed sample number was 662 and 1073, respectively, taking into consideration the availability of both the biomarkers of infection (CRP and AGP) for analysis, in order to adjust for infection. In addition, losses in sample number occurred due to inadequate serum in aliquots, haemolysis, and error in labelling of sample identification by the field staff. This resulted in some overall loss of precision in

Table 1. Prevalence of zinc deficiency ${ }^{*}+\neq$

(Number of subjects, percentages and $95 \%$ confidence intervals)

\begin{tabular}{lccc}
\hline Population & $n$ & $\%$ & $95 \% \mathrm{Cl}$ \\
\hline PSAC§ & & & \\
$\quad$ National & 662 & 44.6 & $34 \cdot 3,54 \cdot 9$ \\
$\quad$ Rural & 228 & 48.6 & $35 \cdot 8,61 \cdot 4$ \\
Urban & 236 & 29.5 & $17 \cdot 7,41 \cdot 3$ \\
Slum & 198 & $51 \cdot 7$ & $40 \cdot 8,62 \cdot 7$ \\
NPNLW\| & & & \\
$\quad$ National & 1073 & $57 \cdot 3$ & $51 \cdot 1,63 \cdot 4$ \\
$\quad$ Rural & 391 & $57 \cdot 5$ & $49 \cdot 9,65 \cdot 1$ \\
Urban & 359 & 54.5 & $45 \cdot 5,63 \cdot 6$ \\
Slum & 323 & $66 \cdot 4$ & $55 \cdot 1,77 \cdot 6$ \\
\hline
\end{tabular}

PSAC, pre-school-age children; NPNLW, non-pregnant non-lactating women; CRP, C-reactive protein; AGP, $\alpha$-1-acid glycoprotein.

${ }^{*} \mathrm{Zn}$ deficiency is defined as serum Zn level of $<9.9 \mu \mathrm{mol} / \mathrm{l}$ in PSAC and $<10.1 \mu \mathrm{mol} / \mathrm{l}$ in NPNLW ${ }^{(1)}$.

† Adjusted for elevated CRP (>10 mg/l) or elevated AGP ( $>1 \mathrm{~g} / \mathrm{l})$ by mathematical correction $^{(12,13)}$.

$\ddagger$ Estimates weighted to represent at the population level.

§ Age 6-59 months.

|l Age 15-49 years. the prevalence estimates: $10 \cdot 3 \%$ precision instead of the stipulated $7 \%$ in PSAC and $6.2 \%$ precision in NPNLW in place of $6 \%$ (Table 1 and Supplementary Table S3).

\section{Statistical analysis}

We performed the statistical analyses using STATA 10.0 SE (StataCorp LP). We calculated the key proportion estimates with a $95 \% \mathrm{CI}$; the mean estimates were calculated with standard deviations through one-way ANOVA. Pearson's $\chi^{2}$ test was used to compare proportions. Projected estimates of the population in the three strata (rural, urban and slum) in 2011 were $122 \cdot 6,23 \cdot 3$ and $5 \cdot 5$ million, respectively ${ }^{(16,17)}$. A total of fifty primary sampling units (PSU) were selected from each stratum, hence resulting in differential selection probabilities and representation across the strata. Sampling weights were applied to the households in each stratum to compensate for the differential representation and to derive weighted national estimates combining the estimates of the three strata. Prior to performing statistical tests, we treated the variables with skewed distribution with logarithmic transformation to convert into normal distribution. Statistical analyses, e.g. proportion estimates, one-way ANOVA and multivariate regression analyses were performed on weighted data. Through using the cluster option in STATA, the analyses, including the regression models, were adjusted for clustering of data at the unit of the randomisation level (PSU). The relevant socio-economic, demographic and dietary intake predictor variables which are logically presumed to have association with serum $\mathrm{Zn}$ were entered in univariate linear regression or bivariate analysis. If there was a significant association with serum $\mathrm{Zn}$ at $P<0.05$ and it had the expected sign mark (i.e. plus or minus sign of the coefficient according to the logical expectation), the variables were selected for the multivariate regression ${ }^{(18)}$. Interaction analyses were performed taking into consideration the variables that logically appear to be interacting in determining serum $\mathrm{Zn}$ status. The predictor variables, which are assumed to have interaction, were entered in the initial regression analyses as an interaction term along with the interacting predictors. If the regression

Table 2. Mean zinc concentration in serum $(\mu \mathrm{mol} / 1)+\S$ (Mean values and standard deviations)

\begin{tabular}{|c|c|c|c|c|}
\hline & \multicolumn{2}{|c|}{ PSAC\| } & \multicolumn{2}{|c|}{ NPNLWף } \\
\hline & Meanł‡ & SD & 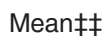 & SD \\
\hline National & $10 \cdot 25$ & $2 \cdot 34$ & $10 \cdot 04$ & 1.72 \\
\hline Rural & $10 \cdot 04$ & 1.75 & $10 \cdot 06^{\star \star}$ & 1.76 \\
\hline Urban & $11.02^{* * *}+\dagger \dagger$ & 3.68 & $10 \cdot 05^{\star}$ & 1.55 \\
\hline Slum & 9.89 & 1.60 & 9.67 & 1.67 \\
\hline
\end{tabular}

PSAC, pre-school-age children; NPNLW, non-pregnant non-lactating women; CRP, C-reactive protein; AGP, $\alpha$-1-acid glycoprotein.

Mean value was significantly different from that for slum: ${ }^{\star} P=0.017$, ${ }^{\star *} P=0.012$, *** $P<0.001$.

††† Mean value was significantly different from that for rural $(P<0.001)$

$\ddagger$ Adjusted for elevated CRP ( $>10 \mathrm{mg} / \mathrm{l})$ or elevated AGP ( $>1 \mathrm{~g} / \mathrm{l})$ by mathematical correction $^{(11,12)}$.

$\S$ Estimates weighted to represent at the population level.

Age 6-59 months.

I Age 15-49 years.

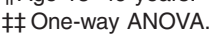


Table 3. Dietary intake of zinc and prevalence of inadequacy of zinc intake (Mean values and standard deviations; percentages with their standard errors)

\begin{tabular}{|c|c|c|c|c|c|c|c|c|c|c|c|c|c|c|c|c|}
\hline & \multicolumn{8}{|c|}{ Intake of $\mathrm{Zn}(\mathrm{mg} / \mathrm{d}) \dagger$} & \multicolumn{8}{|c|}{ Prevalence of inadequate $\mathrm{Zn}$ intake $(\%) \ddagger$} \\
\hline & \multicolumn{2}{|c|}{ National } & \multicolumn{2}{|c|}{ Rural } & \multicolumn{2}{|c|}{ Urban } & \multicolumn{2}{|c|}{ Slum } & \multicolumn{2}{|c|}{ National } & \multicolumn{2}{|c|}{ Rural } & \multicolumn{2}{|c|}{ Urban } & \multicolumn{2}{|c|}{ Slum } \\
\hline & Mean & SD & Mean & SD & Mean & SD & Mean & SD & $\%$ & $\mathrm{SE}$ & $\%$ & $\mathrm{SE}$ & $\%$ & SE & $\%$ & $\mathrm{SE}$ \\
\hline PSAC & $3 \cdot 1$ & $2 \cdot 1$ & $3 \cdot 1$ & $2 \cdot 1$ & $3 \cdot 2^{*}$ & $2 \cdot 0$ & $2 \cdot 6$ & 1.5 & $32 \cdot 6$ & $5 \cdot 0$ & $33 \cdot 0$ & 6.5 & $28 \cdot 7$ & 5.5 & $44 \cdot 1$ & 4.6 \\
\hline NPNLW & 4.2 & 2.5 & $4 \cdot 1$ & $2 \cdot 2$ & $4 \cdot 6^{\star \star}$ & $2 \cdot 3$ & $4 \cdot 1$ & $2 \cdot 0$ & $91 \cdot 1$ & 1.5 & 91.5 & $1 \cdot 8$ & 89.2 & $2 \cdot 7$ & $91 \cdot 1$ & 1.7 \\
\hline
\end{tabular}

PSAC, pre-school-age children; NPNLW, non-pregnant non-lactating women. Mean value was significantly different from that for slum: * $P=0.004$, ${ }^{* *} P=0.001$. †One-way ANOVA.

‡ Inadequate $\mathrm{Zn}$ intake: $<2 \mathrm{mg} / \mathrm{d}$ in PSAC; $<7 \mathrm{mg} / \mathrm{d}$ in NPNLW ${ }^{(1)}$

coefficient for the interaction term was non-significant $(P \geq$ 0.05), it was omitted; however, in cases where the interaction term was statistically significant $(P<0 \cdot 05)$, it was retained and entered into the final multivariate $\operatorname{model}^{(19)}$.

Cronbach's $\alpha$ reliability coefficients for internal consistency of data were calculated considering the variables of SES, dietary consumption, household food insecurity and serum level of Zn. Cronbach's $\alpha$ in data was 0.8179 and 0.8159 , respectively, in PSAC and NPNLW, which is suggestive of good internal consistency ${ }^{(20)}$.

\section{Results}

The national prevalence of $\mathrm{Zn}$ deficiency in pre-school children was $44.6 \%$ (Table 1). It was 29.5 , 48.6 and $51.7 \%$, respectively, in the urban, rural and slum strata. Of the NPNLW, $57 \cdot 3 \%$ suffered from $\mathrm{Zn}$ deficiency at the national level; the prevalence being highest in women living in slums $(66.4 \%)$. The national mean of serum $\mathrm{Zn}$ was 10.2 and $10.04 \mu \mathrm{mol} / 1$ in PSAC and the NPNLW, respectively. The mean level of serum $\mathrm{Zn}$ appeared to be higher in the urban stratum than in the slum stratum in both the populations $(P<0.001$, $P=0 \cdot 017$, respectively) (Table 2 ).

The prevalence of inadequate intake of $\mathrm{Zn}$ in PSAC was $32.6 \%$ at the national level. The respective estimates for rural, urban and slum domains were 33.0, $28 \cdot 7$ and $44 \cdot 1$ $\%$. In NPNLW, 91.1\% had inadequate intake of $\mathrm{Zn}$ at the national level; by and large the estimates remained at similar levels across the strata (Table 3 ). The national average consumption of dietary $\mathrm{Zn}$ in PSAC was $3.1 \mathrm{mg} / \mathrm{d}$, the urban intake being higher than in slums $(3.2 v .2 .6 \mathrm{mg} / \mathrm{d} ; P=$ 0.004). At the national level mean intake of $\mathrm{Zn}$ in NPNLW was $4.2 \mathrm{mg} / \mathrm{d}$. The urban women consumed higher amounts than their peers from slums $(4.6 \mathrm{mg} v .4 .1 \mathrm{mg} / \mathrm{d} ; P$ =0.001; Table 3). Fig. 1 further depicts the relative intake profile.

Less than 1.0 and $6.4 \%$ of the NPNLW aged $15-18$ and 19-49 years, respectively, met the RDA for $\mathrm{Zn}^{(21)}$. In PSAC, $44.7 \%$ of the 2 - to 3 -year-olds and $11.4 \%$ of the 4 - to 5 -yearolds met the $\mathrm{RDA}^{(21)}$ (Table 4). Mean intake of $\mathrm{Zn}$ was $2 \cdot 8$ and $3.2 \mathrm{mg} / \mathrm{d}$ in 2 - to 3 - and 4 - to 5 -year-old groups, respectively; it was 4.0 and $4.3 \mathrm{mg} / \mathrm{d}$ in NPNLW aged $15-18$ and
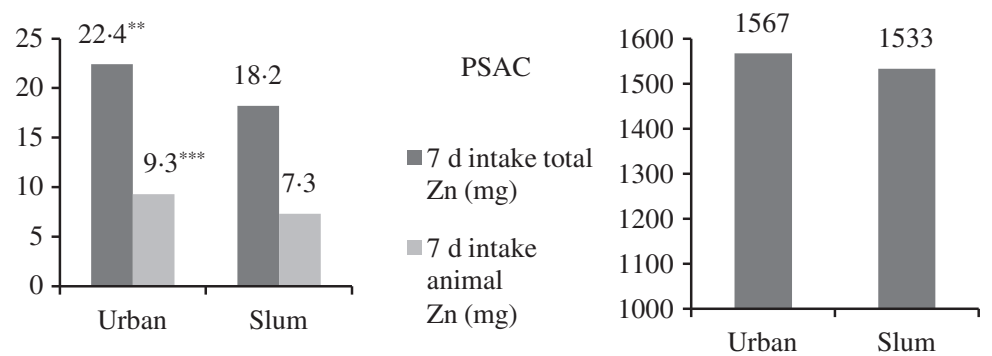

\section{PSAC \\ - 7 d intake phytate (mg)}

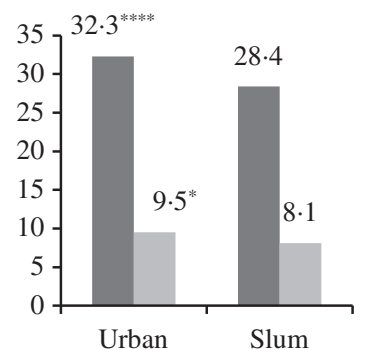

NPNLW
$7 \mathrm{~d}$ intake tota
Zn (mg)

$7 \mathrm{~d}$ intake
animal
Zn (mg)

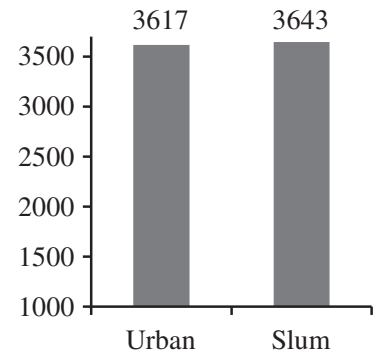

NPNLW

$7 \mathrm{~d}$ intake phytate $(\mathrm{mg})$

Fig. 1. Comparative intake of dietary zinc and phytate in urban and slum strata. Intakes of total zinc and animal-source zinc were significantly higher in the urban stratum than in the slum stratum in both the pre-school-age children (PSAC) and non-pregnant non-lactating women (NPNLW) populations: $22.4 \mathrm{mg} / 7 \mathrm{~d}$ (urban) $v$. $18.2 \mathrm{mg} / 7 \mathrm{~d}$ (slum) $(P=0.004)$ and $9.3 \mathrm{mg} / 7 \mathrm{~d}$ (urban) v. $7.3 \mathrm{mg} / 7 \mathrm{~d}(\mathrm{slum})(P=0.005)$, respectively, for total and animal-origin zinc in PSAC. However, intake of phytate was at similar levels: $1567 \mathrm{mg} / 7 \mathrm{~d}$ (urban) $v .1533 \mathrm{mg} / 7 \mathrm{~d}$ (slum) (NS) in PSAC. Similar profiles of the intake were observed in NPNLW. Significantly different from slum: * $P=0.01,{ }^{* *} P=0.004,{ }^{* * *} P=0.005,{ }^{* \star * *} P=0.001$. 
Table 4. Intake of zinc $v$. RDA

(Mean values with their standard errors; percentages with their standard errors)

\begin{tabular}{|c|c|c|c|c|c|c|c|c|c|}
\hline \multirow[b]{2}{*}{ Population } & \multirow{2}{*}{$\begin{array}{l}\text { A: RDA } \\
(\mathrm{mg} / \mathrm{d})^{\star}\end{array}$} & \multicolumn{2}{|c|}{$\begin{array}{l}\text { B: \% population } \\
\text { meeting RDA }\end{array}$} & \multicolumn{2}{|c|}{$\begin{array}{l}\text { C: intake } \\
(\mathrm{mg} / \mathrm{d})\end{array}$} & \multirow{2}{*}{$\begin{array}{l}\text { D: intake as } \\
\% \text { of RDA† }\end{array}$} & \multicolumn{2}{|c|}{$\begin{array}{c}\text { E: intake of animal } \\
\quad \mathrm{Zn}(\mathrm{mg} / \mathrm{d})\end{array}$} & \multirow{2}{*}{$\begin{array}{c}\mathrm{F}: \% \text { animal } \mathrm{Zn} \text { to } \\
\text { total intake } \neq\end{array}$} \\
\hline & & $\%$ & $\mathrm{SE}$ & Mean & $\mathrm{SE}$ & & Mean & $\mathrm{SE}$ & \\
\hline PSAC 2-3 years & 3 & $44 \cdot 7$ & $5 \cdot 3$ & $2 \cdot 8$ & 0.2 & 93.6 & $1 \cdot 13$ & 0.1 & $40 \cdot 2$ \\
\hline PSAC 4-5 years & 5 & 11.4 & 3.4 & $3 \cdot 2$ & 0.3 & 64.0 & $1 \cdot 15$ & $0 \cdot 1$ & $35 \cdot 9$ \\
\hline NPNLW 15-18 years & 9 & 0.5 & 0.03 & 4.0 & 0.2 & 44.4 & 1.33 & 0.1 & $33 \cdot 2$ \\
\hline NPNLW 19-49 years & 8 & $6 \cdot 4$ & $1 \cdot 3$ & 4.3 & 0.2 & 53.6 & 1.28 & 0.1 & 29.8 \\
\hline
\end{tabular}

PSAC, pre-school-age children; NPNLW, non-pregnant non-lactating women.

* Institute of Medicine ${ }^{(21)}$.

† $\mathrm{D}=\mathrm{C} / \mathrm{A} \times 100$.

$\ddagger \mathrm{F}=\mathrm{E} / \mathrm{C} \times 100$.

19-49 years, respectively. Intake of animal-source $\mathrm{Zn}$ was $1.13-1.15 \mathrm{mg} / \mathrm{d}$ in PSAC and $1.28-1.33 \mathrm{mg} / \mathrm{d}$ in NPNLW according to age subgroups (Table 4$)$. Intake of animal-origin Zn progressively increased as household SES and household expenses were higher; an increasing level of food insecurity was associated with progressively decreasing intake in children and women. However, intake of phytate remained at similar levels irrespective of SES and household food security status (Table 5).

According to dietary patterns of 'mixed' and 'cereal-based' diets, inadequacy of $\mathrm{Zn}$ intake in women was pervasively prevalent at 90 and $100 \%$, respectively. As per dietary type mean intakes of $\mathrm{Zn}$ were 4.5 and $2.4 \mathrm{mg} / \mathrm{d}$, respectively $(P<0.001$; Table 6$)$. In accordance with the absorption pattern for mixed and cereal-based diets ${ }^{(1)}$, the amount of absorbed $\mathrm{Zn}$ was 1.41 and $0.56 \mathrm{mg} / \mathrm{d}$ which fulfilled 75.8 and $30.1 \%$ of physiological requirements, respectively. Intake of animal-source food, according to mixed and cereal-based diets was: meat, 27.6 $v$.
$6.7 \mathrm{~g} / \mathrm{d}(P<0.001)$; fish, 58.6 v. $22.5 \mathrm{~g} / \mathrm{d}(P<0.001)$; and eggs, $11.7 v .3 .4 \mathrm{~g} / \mathrm{d}(P<0.001)$, respectively. Intake of cereals was 337.1 and $457.4 \mathrm{~g} / \mathrm{d}$, respectively $(P<0 \cdot 001)$.

By and large, there was an upward gradient in serum levels of $\mathrm{Zn}$ concurring with progressively increased intake of dietary $\mathrm{Zn}$ in PSAC; however, in NPNLW that trend was not observed (Table 7).

Table 8 shows the results of the multivariate linear regression analyses stating associations of serum $\mathrm{Zn}$ status in the studied populations after controlling for the relevant covariates. Multivariate linear regression analyses suggested that household expenses $(\beta=0.13 ; P=0.007), \mathrm{Hb}(\beta=0 \cdot 10 ; P=0.005)$, intake of animal-source $\mathrm{Zn}(\beta=0.096 ; P=0.02)$ and asset score $(\beta=$ $0.11 ; P=0.03)$ determined higher levels of serum $\mathrm{Zn}$ in NPNLW. Non-agricultural occupation of the household head was nearly positively associated with serum $\mathrm{Zn}$ in NPNLW $(\beta=0.07 ; P=0.054)$. Intake of plant-source $\mathrm{Zn}$ determined the lower status of $\mathrm{Zn}$ in NPNLW $(\beta=-0 \cdot 13 ; P=0 \cdot 001)$.

Table 5. Intake of animal-source zinc and phytate by socio-economic status (SES) and household food insecurity (Mean values and standard deviations)

\begin{tabular}{|c|c|c|c|c|c|c|}
\hline & \multicolumn{2}{|c|}{$\begin{array}{l}\text { Intake of animal-source } \mathrm{Zn} \\
\qquad(\mathrm{mg} / \mathrm{d})\end{array}$} & \multicolumn{2}{|c|}{ 7-d intake of phytate $(\mathrm{mg})$} & \multicolumn{2}{|c|}{$\begin{array}{l}\text { Household spending (USD/ } \\
\text { month) }\end{array}$} \\
\hline & Mean‡ & $\mathrm{SD}$ & Mean‡ & SD & Mean‡ & SD \\
\hline \multicolumn{7}{|l|}{ NPNLW } \\
\hline Poorest & $0.8^{\mathrm{a}}$ & 0.7 & 3388 & 1693 & $76 \cdot 8^{\mathrm{a}}$ & 30.4 \\
\hline Middle & $1.4^{\mathrm{b}}$ & $1 \cdot 1$ & 3533 & 1367 & $125 \cdot 5^{\mathrm{b}}$ & 57.1 \\
\hline Richest & $2 \cdot 1^{\mathrm{c}}$ & 1.2 & 3521 & 1335 & $225.9^{c}$ & $121 \cdot 3$ \\
\hline \multicolumn{7}{|l|}{ PSAC } \\
\hline Poorest & $0.6^{\mathrm{a}}$ & 0.7 & 1636 & 698 & $76 \cdot 3^{a}$ & 28.9 \\
\hline Middle & $1.3^{\mathrm{b}}$ & 0.8 & 1782 & 712 & $124 \cdot 3^{\mathrm{b}}$ & $72 \cdot 1$ \\
\hline Richest & $1.8^{\mathrm{C}}$ & 1.1 & 1546 & 659 & $212 \cdot 5^{\mathrm{c}}$ & $111 \cdot 1$ \\
\hline \multicolumn{7}{|l|}{ NPNLW } \\
\hline FS & 1.6 & $1 \cdot 1$ & 3524 & 1364 & $146 \cdot 1$ & 96.9 \\
\hline MI & $0.9^{*}$ & 0.8 & 3626 & 1806 & $101.9^{\star}$ & 48.9 \\
\hline SI & $0.7^{\star}$ & 0.7 & 3281 & 1634 & $98 \cdot 7^{\star}$ & 58.5 \\
\hline \multicolumn{7}{|l|}{ PSAC } \\
\hline FS & 1.5 & 1.0 & 1700 & 574 & 144.4 & $92 \cdot 1$ \\
\hline MI & $0.9^{*} \dagger$ & 0.9 & 1756 & 1126 & $95 \cdot 2^{*}$ & 41.9 \\
\hline SI & $0.5^{\star}$ & 0.5 & 1562 & 765 & $81 \cdot 1^{\star}$ & $49 \cdot 8$ \\
\hline
\end{tabular}

USD, US dollars; NPNLW, non-pregnant non-lactating women; PSAC, pre-school-age children; FS, food secure; MI, moderate insecure; SI, severe insecure.

a,b,c Mean values within a column within a category with unlike letters were significantly different $(P<0.001)$.

* Mean value was significantly different from that for $\mathrm{FS}(P<0.001)$.

$\dagger$ Mean value was significantly different from that for $\mathrm{SI}(P=0.001)$.

$\ddagger$ One-way ANOVA. 


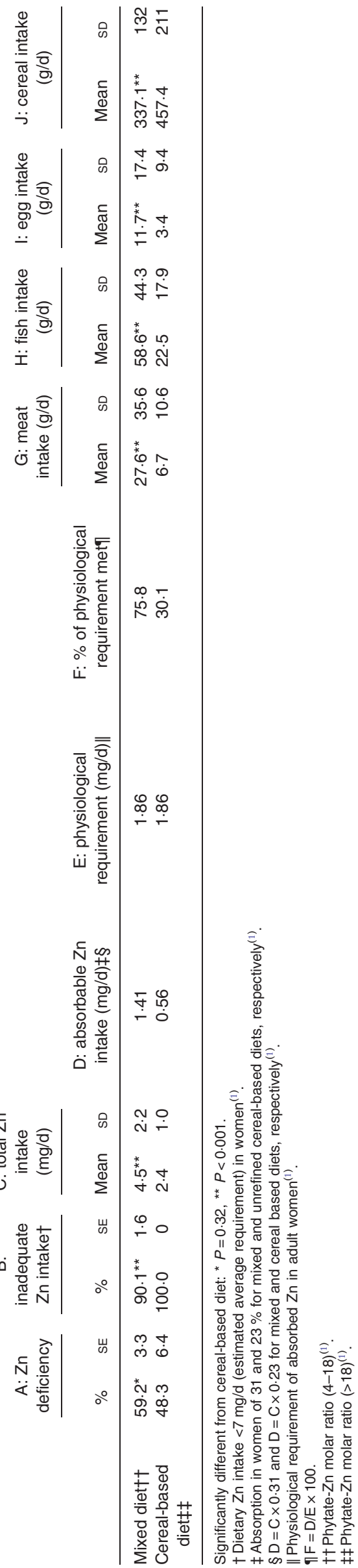

Table 7. Dietary intake of zinc and serum levels of zinc (Mean values with their standard errors)

\begin{tabular}{|c|c|c|c|c|}
\hline \multirow{2}{*}{$\begin{array}{l}\text { Intake levels } \\
\text { of } \mathrm{Zn}(\mathrm{mg} / \mathrm{d})\end{array}$} & \multicolumn{2}{|c|}{$\begin{array}{l}\text { Intake of } Z n \\
(\mathrm{mg} / \mathrm{d})\end{array}$} & \multicolumn{2}{|c|}{$\begin{array}{c}\text { Serum Zn } \\
(\mu \mathrm{mol} / \mathrm{l})\end{array}$} \\
\hline & Mean* & SE & Mean* & $\mathrm{SE}$ \\
\hline \multicolumn{5}{|l|}{ PSAC } \\
\hline $2.5-3.49$ & 3.0 & 0.04 & 9.74 & 0.24 \\
\hline $3.5-4.49$ & 3.9 & 0.03 & 9.81 & 0.26 \\
\hline $4.5-5.49$ & 4.9 & 0.05 & $10 \cdot 18$ & 0.50 \\
\hline $5.5-6.49$ & $6 \cdot 1$ & 0.07 & $10 \cdot 42$ & 0.66 \\
\hline \multicolumn{5}{|l|}{ NPNLW } \\
\hline $2.5-3.49$ & 2.9 & 0.03 & $10 \cdot 16$ & 0.14 \\
\hline $3.5-4.49$ & 4.0 & 0.03 & 9.74 & 0.23 \\
\hline $4.5-5.49$ & $5 \cdot 0$ & 0.02 & 9.66 & 0.27 \\
\hline $5 \cdot 5-6.49$ & 6.0 & 0.04 & $10 \cdot 29$ & 0.46 \\
\hline $6.5-7.49$ & $7 \cdot 0$ & 0.04 & $10 \cdot 77$ & 0.38 \\
\hline $7.5-8.49$ & 7.9 & 0.06 & $10 \cdot 19$ & 0.58 \\
\hline
\end{tabular}

PSAC, pre-school-age children; NPNLW, non-pregnant non-lactating women. * One-way ANOVA.

Residence in an urban area was associated with higher serum $\mathrm{Zn}$ in PSAC compared with their peers from slum areas $(\beta=$ 0.33 ; $P=0.03)$. Intake of plant-origin $\mathrm{Zn}$ was associated with lower status of $\mathrm{Zn}$ in PSAC ( $\beta=-0.13$; $P=0.038)$, while intake of animal-source $\mathrm{Zn}$ was nearly associated with higher levels of serum $\mathrm{Zn}(\beta=0.13 ; P=0.07)$.

\section{Discussion}

The finding of $44 \%$ prevalence of subclinical $\mathrm{Zn}$ deficiency in preschool children was close to the contemporary stunting prevalence of $41 \%$ in Bangladesh ${ }^{(3)}$, reaffirming the notion that the stunting estimate can be a proxy indicator of $\mathrm{Zn}$ undernutrition in children. The dietary intake of $\mathrm{Zn}$ in the present study (Table 3) was consistent with a contemporary study which reported intake of $2.5 \mathrm{mg}$ in young children and $5.5 \mathrm{mg}$ in women in two subdistricts ${ }^{(15)}$. The same study reported the prevalence of inadequate intake of $\mathrm{Zn}$ to be 22 and $94 \%$ in children and women, respectively, which approximately corresponds to our findings (Table 3).

In PSAC, increasing intake of $\mathrm{Zn}$ to roughly twice the amount (from 3.0 to $6.1 \mathrm{mg}$ ) was associated with a $7 \%$ increment in serum Zn level (from 9.74 to $10.42 \mu \mathrm{mol} / 1$; Table 7). A recent meta-analysis pooling all eligible randomised controlled trials of $\mathrm{Zn}$ supplementation modelled that doubling of $\mathrm{Zn}$ intake was associated with a $9 \%$ increment in serum Zn levels ${ }^{(22)}$. Hence our observation of a $7 \%$ increase from this cross-sectional national survey is by and large consistent with the experimentally designed global model predicting $\mathrm{Zn}$ supplementation and its reflection in serum status. This is an important finding in relation to the designing of $\mathrm{Zn}$ promoting interventions for children in the country. In NPNLW, the approximated doubling of intake (from 2.9 to $6.0 \mathrm{mg}$, from 4.0 to $7.9 \mathrm{mg}$; Table 7) was associated with a less marked increase in serum $\mathrm{Zn}(1.2$ and $4.6 \%$, respectively). Somewhat inconsistent $Z n$ status in NPNLW in relation to dietary intake perhaps has resulted from the fact that $\mathrm{Zn}$ status varies with exercise, stress, starvation and timing of food intake ${ }^{(23)}$. 
Bangladeshi women are likely to experience these in day-to-day affairs. However, these factors were not explored in the survey.

The multivariate regression showed intake of animal-source Zn was associated with a higher level of serum $\mathrm{Zn}$ in NPNLW (Table 8). The underlying mechanism is unclear; however, other studies reported animal protein being associated with a greater percentage absorption of dietary $\mathrm{Zn}^{(24,25)}$.

Household expenses which signify household spending capacity were associated with a higher level of serum $\mathrm{Zn}$ in NPNLW. The underlying mechanism into this is not clear; however, it might be attributed to the higher consumption of higher bioavailable animal-origin $\mathrm{Zn}$ by women from households with higher financial status (Supplementary Table S1). Multivariate regression showed that $\mathrm{Hb}$ level was positively associated with serum $\mathrm{Zn}$ in NPNLW (Table 8). Complementing this, the prevalence of subclinical $\mathrm{Zn}$ deficiency was found to be higher in anaemic women than in nonanaemics (Supplementary Table S1). This might be explained by common dietary sources of $\mathrm{Zn}$ and $\mathrm{Fe}$ or the possible role of $\mathrm{Zn}$ in erythropoiesis ${ }^{(26-28)}$.

Multiple regressions showed that the PSAC living in urban areas had higher levels of serum $\mathrm{Zn}$ compared with slum areas. It is in agreement with a lower prevalence of subclinical $\mathrm{Zn}$ deficiency in urban PSAC than their peers in the slums (Table 1). The underlying reason is difficult to explain; however, we assume that a 23.1 and $27.4 \%$ higher intake of total and animal-source $\mathrm{Zn}$, respectively, might have accounted for the higher status of serum $\mathrm{Zn}$ in urban PSAC (Fig. 1). On the other hand, in NPNLW, urban residence was not associated with higher status of $\mathrm{Zn}$ (Table 8). Underlying this is perhaps the intakes of total and animal-source $\mathrm{Zn}$ which were only marginally higher (13.7 and $17.2 \%$, respectively; Fig. 1) in urban women, while the intake of phytate was at similar levels.

Household asset score determined higher status of $\mathrm{Zn}$ in NPNLW. This could be plausibly explained by differential intakes of higher bioavailable animal-origin $\mathrm{Zn}$ which was about 2.5 times higher in the 'richest' households than their peers from the 'poorest' (Table 5). However, in PSAC the asset score was not a predictor of $\mathrm{Zn}$ status. The reason for the differential relationship can be explained by the bioavailability of $\mathrm{Zn}$, an issue that perhaps affects women more in Bangladesh. This is evident from the data in Table 5; for example, in the 'poorest' SES, while women's consumption of animal-source $\mathrm{Zn}$ was $33 \%$ higher than in the 'poorest' PSAC $(0.8 v .0 .6 \mathrm{mg} / \mathrm{d})$, the intake of phytate ( $\mathrm{Zn}$ chelator) was $207 \%$ higher in the poor women, compared with the poor young children (3388 v. $1636 \mathrm{mg} / 7 \mathrm{~d})$. Thus, the PSAC are likely to be affected less than the women in relation to bioavailability of $\mathrm{Zn}$ as a result of a lower consumption of phytate. This might lead to a relatively favourable bioavailability of $\mathrm{Zn}$ in PSAC across a wide range of SES.

Dietary intake of phytate was at similar levels across the SES or household food security status in both the populations (Table 5). This is perhaps one of the fundamental issues behind the population-wide high prevalence of subclinical $\mathrm{Zn}$ undernutrition in Bangladesh.

The strength of the study lies at the consideration of multiple domains - rural, urban and slum, where status of $\mathrm{Zn} \mathrm{nu-}$ trition and attribution of underlying correlates, such as, SES and food consumption status were different, and thus providing a representative status of $\mathrm{Zn}$ nutrition of the country. Although the semi-quantitative FFQ has been increasingly used and validated in other countries ${ }^{(7-10)}$, it is new in Bangladesh, and hence, it was not validated in Bangladeshi populations. While this is a limitation of the study, when comparing the intake data in the survey with another contemporary study in the country ${ }^{(15)}$ in nearly comparable population groups, the results appear to be similar (Table 3, Supplementary Table S2). Although the semi-quantitative FFQ has been validated for $\mathrm{Zn}^{(7,8)}$; it is not directly validated

Table 8. Multivariate regression determining zinc level in serum in pre-school-age children (PSAC) and non-pregnant non-lactating women (NPNLW)

\begin{tabular}{|c|c|c|c|c|c|c|}
\hline \multirow[b]{2}{*}{ Covariates } & \multicolumn{3}{|c|}{ PSAC $^{*}$} & \multicolumn{3}{|c|}{ NPNLW† } \\
\hline & Coefficient & $P$ & $\beta$ & Coefficient & $P$ & $\beta$ \\
\hline $\mathrm{Hb}$ & 0.001 & 0.98 & 0.0009 & $0 \cdot 18$ & 0.005 & $0 \cdot 10$ \\
\hline Household expenses & 0.18 & 0.43 & 0.06 & 0.42 & 0.007 & 0.13 \\
\hline $\begin{array}{l}\text { Age } \\
\text { Occupation of household head }\end{array}$ & 0.014 & 0.22 & 0.08 & -0.012 & -0.07 & -0.07 \\
\hline $\begin{array}{l}\text { Non-agricultural (reference agricultural) } \\
\text { Women's education }\end{array}$ & 0.29 & $0 \cdot 21$ & 0.085 & 0.27 & 0.054 & 0.07 \\
\hline Secondary (reference below secondary) & 0.17 & 0.59 & 0.033 & -0.003 & 0.98 & -0.0005 \\
\hline Intake of animal-source $\mathrm{Zn}$ & 0.00003 & 0.07 & 0.13 & 0.00002 & 0.02 & 0.096 \\
\hline Intake of plant-source Zn & -0.000025 & 0.038 & -0.13 & -0.00002 & 0.001 & -0.13 \\
\hline Asset score & 0.08 & 0.58 & 0.05 & 0.23 & 0.03 & 0.11 \\
\hline Area of residence & & & & & & \\
\hline Urban (reference slum) & 1.37 & 0.03 & 0.33 & 0.18 & 0.64 & 0.04 \\
\hline HFIAS score & 0.04 & $0 \cdot 12$ & $0 \cdot 11$ & 0.02 & 0.10 & 0.066 \\
\hline
\end{tabular}

HFIAS, Household Food Insecurity Access Scale.

* Interaction terms - (occupation of household head $\times$ intake of animal-source $\mathrm{Zn}$ ), (occupation of household head $\times$ intake of plant-source $\mathrm{Zn}$ ), (asset score $\times$ intake of animalsource $\mathrm{Zn}$ ), (household expenses $\times$ intake of animal-source $\mathrm{Zn}$ ), (stratum $\times$ intake of animal-source $\mathrm{Zn}$ ), and (household expenses $\times$ educational status of women) were separately assessed through initial regression equations, along with component predictors. However, none of the interaction terms reached statistical significance level at $P<0.05$ except for (household expenses $\times$ occupation of household head) $(P=0.049)$, which was considered in the final multivariate model; however, it had a non-significant interaction $(P=0.44)$ and as such was removed from the model.

$\dagger$ Interaction terms - all the interaction terms assessed for the PSAC were tested in NPNLW. In the initial regression analyses none had significant interaction except for the household expenses $\times$ intake of animal-source $\mathrm{Zn}(P=0.03)$. It was considered in the final multivariate model where it is reported to have significant interaction $(P=0.01)$ 
for phytate, which is a limitation of the study. However, the tool is validated for cereals, beans and dietary fibre ${ }^{(7,8)}$, and these food components are the major sources of phytate.

The timing of blood sample collection in relation to the last meal is important for assessing serum $\mathrm{Zn}$ status ${ }^{(29)}$. However, we could not arrange a time protocol for sample collection due to the limited amount of time to complete data collection in the clusters. Also, because the respondents visited the collection centres according to their convenience in the day, this was a limitation as well.

In conclusion, subclinical $\mathrm{Zn}$ deficiency is pervasively prevalent in Bangladesh in vulnerable populations. The worst hit by the condition are women, people living in lower SES and in the slums. A high burden of $\mathrm{Zn}$ undernutrition is related to the intake lower than the requirements, especially that of the higher bioavailable animal-source $\mathrm{Zn}$ and the high intake of plant-origin phytate-bound $\mathrm{Zn}$. Bangladesh needs to strengthen research and programmes related to $\mathrm{Zn}$ supplementation, biofortification, industrial fortification and phytate-reducing technologies in the food system in the short and medium term, along with promotion of animal-source $\mathrm{Zn}$ for all in the long run.

\section{Supplementary material}

The supplementary material for this article can be found at http://dx.doi.org/10.1017/jns.2016.17

\section{Acknowledgements}

The study acknowledges support of UNICEF Bangladesh. We thank the national technical committee for guidance into the study design, data collection and data analysis. We thank the local government officials, field-level staff members of the Institute of Public Health Nutrition, Government of People's Republic of Bangladesh, and the survey participants from all over Bangladesh.

The study was funded by UNICEF Bangladesh (grant number: SC/2008/0475-, GC/2005/6012-01). UNICEF Bangladesh was involved in the conceptualisation and designing of the study and review of the manuscript but had no role in data collection, data analysis, data interpretation and manuscript writing.

S. R., T. A., A. S. R., N. A., I. A. C. and A. M. S. A. conceived and designed the study. S. R., T. A., F. P. C. and S. M. M. R. acquired the data. S. R. and N. A. analysed the data. S. R., A. S. R. and N. A. interpreted the data. S. R. drafted the manuscript. T. A., S. I., A. S. R., N. A., S. M. M. R. and I. A. C. contributed to redrafting and finalising the manuscript. S. R. has full access to all the data in the study and had final responsibility for the decision to submit for publication. All authors read and approved the final manuscript.

There are no conflicts of interest.

\section{References}

1. Brown KH, Rivera JA, Bhutta Z, et al. (2004) International Zinc Nutrition Consultative Group (IZiNCG) technical document \#1.
Assessment of the risk of zinc deficiency in populations and options for its control. Food Nutr Bull 25, 1 Suppl. 2, S99-S203.

2. Bhutta ZA, Black RE, Brown KH, et al. (1999) Prevention of diarrhea and pneumonia by zinc supplementation in children in developing countries: pooled analysis of randomized controlled trials. J Pediatr 135, 689-697.

3. National Institute of Population Research and Training (NIPORT), Mitra and Associates, and ICF International (2013) Bangladesh Demographic and Health Survey 2011. Dhaka, Bangladesh and Calverton, MD: NIPORT, Mitra and Associates, and ICF International.

4. BBS/UNICEF (2010) Multiple Indicator Cluster Survey (MICS) 2009, Progotir Pathey, Volume I: Technical Report. http://www. unicef.org/bangladesh/MICS-PP-09-v10.pdf (accessed May 2016).

5. Gwatkin DR, Rustein S, Johnson K, et al. (2000) Socioeconomic Differences in Health, Nutrition, and Population in Bangladesh, HNP/ Poverty Thematic Group Working Paper. Washington, DC: The World Bank.

6. Coates J, Swindale A \& Bilinsky P (2007) Household Food Insecurity Access Scale (HFLAS) for Measurement of Food Access: Indicator Guide, version 3. Washington, DC: Food and Nutrition Technical Assistance III Project.

7. Cheng Y, Yan H, Dibley MJ, et al. (2008) Validity and reproducibility of a semi quantitative food frequency questionnaire for use among pregnant women in rural china. Asia Pac J Clin Nutr 17, 166-177.

8. Zhang H, Qiu X, Zhong C, et al. (2015) Reproducibility and relative validity of a semi quantitative food frequency questionnaire for Chinese pregnant women. Nutr J 14, 56.

9. Tang Y, Liu Y, Xu L, et al. (2015) Validity and reproducibility of a revised semi-quantitative food frequency questionnaire (SQFFQ) for women of age-group 12-44 years in Chengdu. J Health Popul Nutr 33, 50-59.

10. Buch Andersen T, Perez-Cueto FJA, Toft U, et al. (2016) Relative validity and reproducibility of a parent-administered semi quantitative FFQ for assessing food intake in Danish children aged 3-9 years. Public Health Nutr 19, 1184-1194.

11. Ali SMK (1991) Conversion Factors and Dietary Calculation. Dhaka: University of Dhaka, Institute of Nutrition and Food Sciences.

12. Islam SN, Khan MNI \& Akhtaruzzaman M (2010) A Food Composition Database for Bangladesh with Special Reference to Selected Ethnic Foods. Dhaka: Institute of Nutrition and Food Sciences, University of Dhaka.

13. Thurnham DI, McCabe LD, Haldar S, et al. (2010) Adjusting plasma ferritin concentrations to remove the effects of subclinical inflammation in the assessment of iron deficiency: a meta-analysis. Am J Clin Nutr 92, 546-555.

14. Engle-Stone R, Haskell MJ, Ndjebayi AO, et al. (2011) Plasma retinol-binding protein predicts plasma retinol concentration in both infected and uninfected Cameroonian women and children. J Nutr 141, 2233-2241.

15. Arsenault JE, Yakes EA, Hossain MB, et al. (2010) The current high prevalence of dietary zinc inadequacy among children and women in rural Bangladesh could be substantially ameliorated by zinc biofortification of rice. J Nutr 140, 1683-1690.

16. Bangladesh Bureau of Statistics (2007) Population Census-2001, National Series. Vol. 1: Analytical Report. Dhaka: Bangladesh Bureau of Statistics, Planning Division, Ministry of Planning, Government of Bangladesh.

17. Center for Urban Studies, National Institute of Population Research and Training \& MEASURE Evaluation (2006) Slums of Urban Bangladesh: Mapping and Census 2005. Dhaka and Chapel Hill, NC: CUS, NIPORT and MEASURE Evaluation.

18. Gelman A \& Hill J (2007) Data Analysis Using Regression and Multilevel/Hierarchical Models, p. 69. New York: Cambridge University Press.

19. Mason J, Gillenwater K, Pugh R, et al. (2012) Practical Analysis of Nutritional Data (PANDA), Section 3. http://www.tulane.edu/ $\sim$ panda3/FS/Computing/regression/interact.htm (accessed March 2015). 
20. George D \& Mallery P (2003) SPSS for Windows Step by Step: A Simple Guide and Reference, 11.0 Update, 4th ed. Boston, MA: Allyn \& Bacon.

21. Institute of Medicine (2002) Dietary Reference Intakes for Vitamin A, Vitamin K, Arsenic, Boron, Chromium, Copper, Iodine, Iron, Manganese, Molybdenum, Nickel, Silicon, Vanadium, and Zinc. Washington, DC: National Academies Press.

22. Moran VH, Stammers AL, Medina MW, et al. (2012) The relationship between zinc intake and serum/plasma zinc concentration in children: a systematic review and dose-response meta-analysis. Nutrients 4, 841-858.

23. Ashwell M, Lambert JP, Alles MS, et al. (2008) How we will produce the evidence-based EURRECA toolkit to support nutrition and food policy. Eur J Nutr 47, 2-16.

24. Sandström B (1992) Dose dependence of zinc and manganese absorption in man. Proc Nutr Soc 51, 211-218.
25. Lönnerdal B (2000) Dietary factors influencing zinc absorption. J Nutr 130, 1378S-1383S.

26. Gibson RS, Abebe Y, Stabler S, et al. (2008) Zinc, gravid, infection and iron but not vitamin B-12 or folate status predict haemoglobin during pregnancy in southern Ethiopia. J Nutr 138, 581-586.

27. de Jong N, Ampong Romano AB \& Gibson RS (2002) Zinc and iron status during pregnancy of Filipino women. Asia Pac J Clin Nutr 11, 186-193.

28. Folin M, Contiero E \& Vaselli GM (1994) Zinc content of normal human serum and its correlation with some hematic parameters. Biometals 7, 75-79.

29. Arsenault JE, Wuehler SE, López de Romaña D, et al. (2011) The time of day and the interval since previous meal are both associated with young children's plasma zinc concentrations in Peru and Ecuador, and therefore affect estimates of the populations' risk of zinc deficiency. Eur J Clin Nutr 65, 184-190. 